\title{
EDITORIAL
}

\section{GENÉTICA Y RACISMO}

Genetics and Racism

$\mathfrak{E}$ n los primeros días de este año pasó casi desapercibida la noticia de que James Watson había sido despojado de los honores que su centro de trabajo, el Cold Spring Harbor Laboratory (CSHL), de Nueva York, le había conferido: Canciller Emérito, Profesor Emérito Oliver R Grace y Fiduciario Honorario. ${ }^{1}$

James Watson había ganado el Premio Nobel de medicina y fisiología en 1962, junto con Francis Crick y Maurice Wilkins, por haber descubierto la estructura doble helicoidal del ADN en 1953, es un pionero de la secuenciación del genoma y es un icono del mundo científico. El motivo que llevó al CSH La tomar una drástica medida fue que Watson había reiterado en un documental reciente lo que había sostenido en 2007 , que se sentía muy pesimista en cuanto a las políticas sociales occidentales de ayuda a los africanos porque asumen que son tan inteligentes como los blancos. Esta y otras afirmaciones similares hicieron que el CSHL considerara que las declaraciones de Watson eran absolutamente incompatibles con la misión, valores y políticas de la institución. 2,3

Es cierto que la controversia generada por Watson no era nueva; además, él había sido criticado antes también por sus declaraciones sexistas, machistas y anti-semitas. Hubo quienes disculparon a Watson aduciendo su formación conservadora.
El racismo científico es una antigua práctica, data del siglo XVIII, que supone la superioridad racial en base a características físicas, en especial el color de la piel, y que persiste a pesar de las diversas evidencias en su contra. En junio del 2000, el Proyecto Genoma Humano demostró que todos los grupos humanos tienen en común más del 99,9\% de los genes; es decir, la variación genómica en el mundo no permite definir claramente grupos raciales. Además, los estudios indican que las razas socialmente definidas no corresponden a la variación genética subyacente dentro de nuestra especie.,3

También se ha intentado identificar variantes genéticas asociadas con alguna definición de la inteligencia o nivel educativo pero se ha hallado que la genómica subyacente de estos rasgos es compleja, altamente poligénica. Tampoco se ha podido correlacionar los genes con los rasgos físicos. Por otro lado, se ha observado que el ambiente ejerce influencias profundas en la expresión genética. Entonces, cuando las influencias ambientales (clima, alimentación, entorno familiar, entorno social, enfermedad, exposición a contaminantes, etc.) son radicalmente diferentes entre los grupos humanos, especialmente entre aquellos en que, socialmente, unos son dominantes y otros subordinados, no podemos afirmar que un rasgo físico está siendo determinado por los genes. ${ }^{4}$ Todo esto ha sido obviado por Watson, guiado más por sus sentimientos que por la objetividad científica. 
Anecdóticamente, Watson aceptó que se compare su genoma con el de Craig Venter - uno de los primeros secuenciadores del genoma y fundador de Celera Genomics- y el del científico coreano Seong-Jin Kim. Lo que se halló fue que Watson y Venter tenían más genes en común con Seong que entre ellos mismos.

Desafortunadamente, Watson no está solo. Hay muchos otros científicos que opinan de la misma manera. Es de esperar que en el futuro cercano todos tengan conciencia de lo que se conoce a la luz de los avances científicos y no se alimente a las pseudociencias o se contribuya a las falsas creencias populares, como la de aquellos que sostienen que la Tierra es plana, otros que la Tierra es hueca, o aquellos que niegan la evolución de las especies, por citar algunas posturas extravagantes.

Alolargodelahistoria, ciertos gruposhumanos, con determinadas características físicas o culturales ("nosotros/as"), han considerado que otros grupos no son iguales a ellos ("otros / as") o, más aún, que son inferiores. ${ }^{5}$ Esto ha llevado a la violencia: a someterlos o, dado el caso, a pretender exterminarlos. Este proceso suele acompañarse de un trasfondo económico, como el usufructuar los recursos naturales de los sometidos o emplear su fuerza laboral para provecho del grupo dominante. Después de una o dos generaciones, los sometidos fueron considerados como "propiedad" de los dominantes, fueron cosificados y podìan ser tratados o enajenados como tales. Lo relativo de esta supuesta "superioridad" queda en evidencia cuando pueblos que antes fueron dominantes y se creyeron "superiores", después fueron subordinados.

Esa condición de "nosotros / as" y los "otros / as" es lo que se conoce como alterización, esto es cuando un grupo humano se considera patrón o medida de todos los demás. De esta manera, ciertas sociedades "blancas/occidentales" desarrollaron una serie de constructos para diferenciarse o manifestar su supuesta superioridad. ${ }^{5}$ Este fue el caso del cociente de inteligencia (intelelligence quotient, IQ). Si los grupos étnicos no "blanco/occidentales" no tenían un IQ promedio igual o similar al de ellos, se infería que eran "inferiores". Por último, ya no fue necesario el IQ sino que bastaba que no eran "blancos/ occidentales". ${ }^{5}$ Durante el coloniaje español, para ocupar los cargos importantes de la administración o ingresar a la universidad tenía que demostrarse la "limpieza de sangre", esto es padres españoles o descendientes sin atisbos de moro, judío, indio o negro. Pero, recordemos que la península ibérica estuvo poblada sucesivamente por los íberos, fenicios, griegos, cartagineses, lusitanos, romanos y godos hasta que se constituyeron en las comunidades de castellanos, andaluces, gallegos, asturianos, catalanes, vascos, etc., y que en el siglo VIII fueron invadidos y ocupados por los árabes, quienes permanecieron en la península por casi 800 años. Ergo, podemos asumir que la península fue un crisol de genes; entonces, ¿Cómo así se pudo reclamar una "limpieza de sangre"?

Otro ejemplo. A fines de la década de 1930, el nacional socialismo reclamó que los alemanes eran de "raza aria" y que esta era superior a todas las demás "razas". Bajo este supuesto, y con intereses políticos y económicos, se pretendió el exterminio de toda una comunidad cuya ligazón no era siquiera "racial" sino religiosa, la judía. Históricamente, el centro de Europa ha sido campo de batalla de muchos pueblos occidentales y orientales, han ocurrido desplazamientos humanos y ocupaciones en uno y otro sentido geográfico que ha generado mixturas de genes a lo largo del tiempo por lo que jamás se podría reclamar una "pureza de 
raza". Al final de la guerra, Alemania recibió una inyección de genes eslavos; y, en el 2015, el gobierno alemán, en una decisión humanitaria, permitió el ingreso de un millón de refugiados sirios. Otros países europeos hicieron lo mismo aunque en cifras variables. Debemos añadir las migraciones periódicas de quienes buscan mejores condiciones de vida y los rápidos desplazamientos humanos por motivos laborales gracias al transporte moderno. Todo esto, con el transcurrir del tiempo, dará lugar a una natural mezcla de genes en diferentes grados, contribuyendo a lo que siempre ha existido y que es una de las características primordiales para la supervivencia de las especies: la variabilidad genética.

Cuando uno camina por cualquier ciudad, en cualquier parte del mundo, se encuentra con una diversidad de tallas, volúmenes y proporciones corporales, de tonalidades de color de piel, cabello y ojos, de formas de los órganos externos, etc. que permiten una miríada de combinaciones, dando lugar a otro tanto de individuos con ectoscopía diferente. Ahora sabemos que todos estos individuos tienen una carga genética muy parecida $\mathrm{y}$ constituyen la especie humana. Por tanto, pretender que unos son "superiores" a otros bajo supuestos o prejuicios es insostenible. La ciencia da fe de esto.

\section{REFERENCIAS BibliográficAs}

1. Josh Gabbatiss. James Watson: The most controversial statements made by the father of DNA. 13 January 2019. URL disponible en: https: / / www.independent.co.uk/news/ science / james-watson-racis m-sexism-dna-raceintelligence-genetics-double-helix-a8725556.html

2. Solly, Meilan. DNA Pioneer James Watson Loses Honorary Titles Over Racist Comments. January 15, 2019. url disponible en: https://www. smithsonianmag.com/smart-news/dna-pioneerjames-watson-loses-honorary-titles-over-racistcomments-180971266/

3. Ogbunu, C. Brandon. James Watson and the insidiousness of scientific racism. 01.29.19. URL disponible en: https: / / www.wired.com/ story / james-watson-and-scientific-racism/

4. Graves, Joseph. James Watson's racism is a product of his time -- but that doesn't excuse it. January 16, 2019. URL disponible en: https:// edition.cnn.com/2019/01/15/opinions / jameswatson-not-alone-in-racist-thinking-graves / index.html

5. Guzmán Martínez, Grecia. Racismo científico. Qué es y cómo transforma la ciencia para legitimarse. URL disponible en: https:// psicologiaymente.com/cultura/racismo-cientifico

\section{Orear G. Pama Reyna}

Profesor principal. Facultad de Medicina, UPCH. 